\title{
유교와 대순진리회의 심성론(心性論) 비교 연구 A Comparative Study on Theories of the Nature of the Mind in Confucianism and in Daesoon Jinrihoe
}

\author{
윤 용복 *
}

Yoon Yong-bok. Director, The Asian Institute of Religions.

\begin{abstract}
Theories on the nature of the mind aim to accurately describe the nature of the human mind. In other words, these theories are meant to discover what the human mind ultimately is and what its nature is. In this study, I try to understand the theory of the nature of the mind in Daesoon Jinrihoe in connection to similar theories in Confucianism.

Like in Confucianism, the issue of mind is an important subject in Daesoon Jinrihoe. The concept of 'mind' as presented in 'The Jeon-Gyeong' is connected to gods. But in 'The Jeon-Gyeong,' there is no premise that the mind is good or evil. It suggests that the mind is the center of humanity and the universe and that all things depend on the mind. Therefore it is understood that good and evil are revealed according to the actions of the mind. Conscience (良心) and self-interest (私心) are mentioned in 'Essentials of Daesoon Jinrihoe'. If conscience is understood as benevolence (仁) as spoken of by Confucius, or as Moral Knowledge in Mencius's usage, more advanced discussion can be made. If looked upon in that way, one can conclude that conscience is the nature of the
\end{abstract}

* 아시아종교연구원 원장, E-mail: yoonyongb@hanmail.net 
mind and thereby, the nature of humans and their minds is good.

Discussions on the nature of the mind can also be explained in relation to the concept of 'a Singularly-focused Mind (一心)', which was frequently emphasized by Jeungsan. The two mindsets of conscience and self-interest are mentioned, but the original mind is only conscience which exists as the nature of heaven (天性). Self-interest is nothing but an illusion. As Zhu Xi explained that even if a saint (聖人) thought of utterly nothing, he would became a madman, and therefore people should look closely and realize that self-interest is nothing but a delusion. Accordingly, when returning to one's conscience, the orignal state of a singularly-focused mind, it becomes the sort of Singularly-focused Mind that Jeungsan emphasized. In other words, self-interest is a form of greed that is born out of worldly desires.

Key words: Daesoon Jinrihoe, Theories on the Nature of the Mind, Conscience and Self-interest, the Nature of Heaven, a Singularly-focused Mind 


\section{I. 들어가는 말 \\ II. 유교의 심성론 \\ III. 대순진리회에서의 마음 \\ IV. 대순진리회의 심성론 \\ V. 나가는 말}

\section{I. 들어가는 말}

심성론(心性論)이란 말 그대로 인간이 지닌 마음의 본성에 대한 것 을 설명하는 것이다. 다시 말해서 인간은 마음이란 것을 지니고 있는 데, 그것이 과연 무엇인가, 그리고 어떤 성품을 지녔는가를 알아보는 것이다. 심성에 대한 논의는 곧 인간 이해의 여러 측면들 가운데 한 부분을 차지한다. 심성론은 인간관이라는 넓은 주제에 비해 보다 세분 화된 영역에 속하지만, 인간 이해의 중심적 부분을 차지한다고 볼 수 있다. 현대 사회 들어서 마음, 또는 심리의 중요성이 부각되면서 심리 학이나 철학뿐만 아니라 교육, 스포츠, 예술 등 다양한 분야에서 마음 에 대한 연구들이 행해지고 있다. 이는 종교도 예외가 아니어서 심성 론의 대표주자인 유교는 물론이고 불교, 기독교 등의 종교와 원불교와 같은 신종교들에서도 마음에 대한 연구들이 활발히 이루어지고 있다. 대순진리회에서도 마음은 중요한 주제 가운데 하나이다.

따라서 본고에서는 유교의 심성론과의 비교를 통해 대순진리회의 심성론을 이해해 보려고 한다. 대순진리회의 심성론 자체만을 놓고 이 해하는 방법도 있겠지만, 다른 종교와 비교한다면 대순진리회 심성론 
이 좀 더 명확하게 드러날 것이라고 생각하기 때문이다.

유교에서의 심성론은 맹자로부터 비롯된 것으로 알려져 있다.1) 이 후에도 유교에서 심성이라는 주제는 항상 중심적 논의의 대상이었다. 송대의 성리학은 물론이고 성리학을 국가의 지도이념으로 삼았던 조 선시대에도 심성은 중요한 주제였다. 물론 심성이 유교에서만 다루어 졌었던 것은 아니었다. 불교와 도교에서도 마음, 또는 심성에 대한 논 의나 가르침들이 있었지만, 유교와는 다소 다른 차원이라고 생각된다. 심성에 대해 역사적으로 전개된 논의들도 그렇지만 현대 한국 학계의 연구 성과만을 보더라도 다양한 주제의 심성 연구가 유교를 중심으로 이루어지고 있다. 그런 점에서 유교와의 비교가 대순진리회 심성론을 이해하는 데 도움이 될 수 있다고 판단하였다.

연구의 순서는 심성론에 대한 이해를 위해 유교의 심성론을 파악해 보고 다음으로 대순진리회에서 제시하는 마음에 대해 알아볼 것이다. 그리고 유교와의 유사점이나 차이점 등을 토대로 대순진리회 심성론의 특성과 검토되어야 할 문제 등을 중심으로 논의를 진행할 것이다. 유 교의 심성론은 맹자를 시작으로 주자와 퇴계, 그리고 율곡의 논의를 검토해 나갈 것이다. 유교의 심성론은 맹자, 주자, 퇴계, 율곡의 입장이 각기 서로 차이를 보이고 있다. 따라서 일반적 이들 각각의 심성에 대 해 알아볼 것이다. 대순진리회에서 제시하는 마음에 대한 논의는 『전 경』의 내용을 중심으로 살펴보되『대순진리회요람』과『대순지침』, 그 리고 대순진리회의 마음과 관련된 연구들을 검토할 것이다.

대순진리회 심성론의 이해를 위해 다른 종교의 심성론이 아닌 유교 의 심성론을 검토하는 이유는 첫 번째로 대순진리회가 한국에서 시작 된 종교이기 때문에 어떤 형태로든 유교의 영향이 있을 수밖에 없기 때문이며, 두 번째는 한국에서 심성론을 거론할 때 유교가 지니는 성

1) 공자도 마음에 대한 언급을 하지만 『논어』 전체를 통하여 '심'은 6회를 언급하는데 그치고 있다. 공자에게 있어서 마음이란 인간의 자각이나 주체의식 정도를 가리키는 것으로 이해된다. 이상은, 「선진유학의 근본문제와 전승관계에 관한 고찰-공자. 맹 자·순자의 천인관, 심성론을 중심으로」, 『동양철학연구』 17 (1997), pp.278-279. 
격 때문이다. 적어도 마음, 또는 심성에 관한 문제는 유교에서 자유로 울 수 없는데, 이는 불교나 도교도 마찬가지이지만 특히 유교의 영향 이 훨씬 크다고 보기 때문이다. 4장에서는 앞장에서 제시된 유교의 심성론과 대순진리회의 마음에 관한 논의를 비교하여 대순진리회 심 성론의 특성과 함께 검토되어야 할 문제 등도 논의할 예정이다.

대순진리회의 마음과 관련된 기존의 연구들은 매우 많아서 모두를 언급하기에는 무리가 따른다. 다만 기존 연구의 내용들은 거의 대부분 대동소이한데, 주로 마음의 구조와 기능을 설명하는 데 중점을 두고 있다. 대체로 거론되는 것이 전경의 내용을 인용하여 마음은 신이 임 하는 통로이며 몸과 우주를 주관한다는 것에 초점을 맞추고 있다. 이 러한 대순진리회 마음 관련 연구의 경향을 차선근은 인간적 차원과 우주적 차원의 두 가지로 나누고 있다.2) 본고는 이러한 선행 연구들 의 입장을 받아들이면서 여기에 더하여 마음의 본성, 즉 심성에 대한 논의까지 접근해 보려고 한다.

\section{II. 유교의 심성론}

마음(心)에 대한 문제를 구체적으로 지적하고 확장한 것은 맹자부 터이다. 맹자 이전 마음에 대한 논의는 『서경(書經)』에 순임금이 우임 금에게 인심(人心)과 도심(道心)을 구분하여 논하고 있지만3) 맹자에 이르러 마음에 대한 논의가 보다 구체화되었다.

맹자는 인(仁), 의(義), 예(禮), 지(智)의 단서(端緒)로서의 네 가지 마

2) 차선근, 「대순진리회 마음관 연구 서설-해원과 감응을 중심으로, 『신종교연구』 36 (2017), p.115.

3）『書經』, 「虞書 大禹謨, “舜曰 人心惟危 道心惟微 惟精惟一 允執厥中.”; 『中庸』, 「章 句序」, “人心惟危 道心惟微 惟精惟一 允執厥中者 舜之所以授禹也.” 
음이 인간에게 있음을 말하면서 이를 성선설(性善說)의 근거로 제시한다.

사람이 모두 사람에게 차마하지 못하는 마음이 있다고 하는 것은 어린이가 우물에 들어가는 것을 지금 사람이 마침 보고 모두 놀라서 측은한 마음이 있게 될 것인데, 그 이유는 어린이 의 부모와 교제를 맺으려는 것도 아니고, 자기마을의 친구들에 게 명예를 요구하려는 것도 아니며, 그 비난의 소리를 싫어해서 그런 것도 아니다. 이로써 본다면, 측은한 마음이 없으면 사람 이 아니고, 수오하는 마음이 없으면 사람이 아니며, 사양하는 마음이 없으면 사람이 아니고, 시비하는 마음이 없으면 사람이 아니다. 측은한 마음은 인의 단서이고, 수오하는 마음은 의의 단서이고 사양하는 마음은 예의 단서이며, 시비하는 마음은 지 의 단서이다. 사람에게 이 사단이 있는 것은 마치 그에게 사체 가 있는 것과 같다.4)

그런 점에서 맹자는 인간과 금수를 대비시켜 설명하고 있다.

사람이 금수와 다른 점은 아주 적다. 서민은 그것을 버리고 군자는 그것을 가지고 있다. 순임금이 모든 서물(庶物)을 밝히 고 인륜을 자세히 살핀 것은 인의(仁義)에서 비롯된 것이지 인 의를 실제로 행한 것은 아니다.5)

마음에서 비롯되는 본성은 인의만이 아니라 인의예지(仁義禮智) 모 두에 해당된다. 맹자는 인간과 짐승의 차이점을 근거로 인간고유의 도 덕적 본질인 성(性)을 이야기하면서 인간의 본성을 선(善)으로 규정하 고 있다.6) 인간의 본성에 대해 주자(朱子)는 사람과 사물이 모두 하 늘과 땅의 이치를 얻어서 성품이 되고 하늘과 땅의 기운을 얻어 형체

4）『孟子』, 「公孫丑上」, “所以謂人皆有不忍人之心者 今人乍見孺子將入於井 皆有忧惕惻 隱之心 非所以內交於孺子之父母也 非所以要譽於鄉黨朋友也 非惡其聲而然也. 由是觀 之 無惻隱之心 非人也 無差惡之心 非人也 無辭讓之心 非人也 無是非之心 非人也. 惻 隱之心 亿之端也 羞惡之心 義之端也 辭讓之心 禮之端也 是非之心 智之端也.”

5）『孟子』, 離婁下」, “孟子曰人之所以異於禽獸者 幾希 庶民去之 君子存之. 舜明於庶 物 察於人倫 有仁義行 非行仁義也.”

6) 윤지원, 「선진유가인성론소고」, 『공사논문집』 65 (2014), pp.145-146. 
가 되었지만 사람만이 그 사이에 있는 형체와 기운의 바른 것을 얻어 서 그 성품을 완전하게 한 것이 차이점이라고 하였다.7)

마음은 사람들만이, 그리고 모든 사람이 가지고 있는 것인데, 그것 이 인의예지의 출발점이 된다. 그렇기에 맹자는 인간의 도덕적 행위나 선의 가능성을 마음(心)으로부터 찾는다. 따라서 맹자에게 인간의 마 음은 도덕의 본심이다. 마음은 동시에 본성이 되며 그것은 도덕심이고 도덕본성이다. 마음이란 주관적 측면이고 성은 객관적 측면이므로 결 국 마음과 성은 같은 것을 다른 측면에서 말하는 것이 된다.8) 맹자의 성선설은 결국 마음의 본성이 선한 것으로 연결된다. 그렇다면 인간의 본성이 선하다는 것을 인간의 심성이 선하다고 바꾸어 말할 수 있을 것이다. 즉 성선을 심선으로 바꾸어 말할 수 있다. 맹자의 성선설에 대해 풍우란은 진례(陳澧)의 말을 빌려 “성이 선하다는 맹자의 말은 모든 사람이 생래적으로 한결같이 도덕적으로 완전하다는 말이 아니 라 그의 본성 속에 선한 요소나 원칙이 있다는 말"9)이라고 하였다.

송대 성리학에서 마음의 문제는 수양론의 중요 주제이다. 주자(朱子) 는 『서경(書經)』에 나오는 인심도심의 발생근원을 사사로운 형기(形氣) 인 육신과 올바른 성명(性命)이라는 두 근원의 대비구도로 설명한다.10)

마음의 허령지각(虛靈知覺)은 하나일 뿐인데 인심과 도심의 다름이 있다고 하는 것은 혹은 형기의 사사로움에서 생겨나고 혹은 성명의 바름에서 근원하기 때문에 다르게 지각되는 것이 다. 그래서 혹은 위태롭기에 불안하며 혹은 미묘하여 보기가 어 려운 것이다. 그러나 사람은 이 형체를 가지고 있지 않은 이가 없으므로 비록 상지(上智)라도 인심이 없을 수 없고, 또한 이 성품을 가지고 있지 않은 이가 없으므로 하우(下愚)라도 도심이

7）『孟子集註』, 離婁下」, “人物之生 同得天地之理 以営性 同得天地之氣 以営形 其不同 者 獨人於其間 得形氣之正 而能有以全其性 篇少異耳.”

8) 윤지원, 앞의 글.

9) 馮友蘭, 『중국철학사』 상권, 박성규 옮김 (서울: 까치글방, 2013), p.199.

10) 임부연, 「정약용 마음론의 구조와 쟁점-주희와의 비교를 중심으로, 『종교학연구』 20 (2001), p.95. 
없을 수 없다. 그 두 가지가 마음 사이에 섞여 있어 다스릴 바 를 알지 못하면, 위태로운 것은 더욱 위태로워지고, 미묘한 것 은 더욱 미묘해져서 천리의 공변됨이 마침내 인욕의 사사로움 을 이기지 못할 것이다 $\cdots$ 반드시 도심으로 항상 한 몸의 주체 를 삼고 인심이 언제나 그 명령을 따르게 한다면 위태로운 것 이 편안해지고 미묘한 것이 드러나서 동정(動靜)과 운위(云爲) 가 저절로 지나치거나 미치지 못하는 잘못이 없을 것이다.11)

모든 사람에게는 도심과 인심이 내재해 있는데, 도심은 육체의 주재 자이어야 하고 인심은 도심에 종속되어야 한다. 주자는 정이천이 인심 을 인욕(人欲), 도심을 천리(天理)라고 하는 설을 옳다고 하면서 다만 그것이 두 가지가 아니고 마음의 도리에 합하면 천리이고 정옥을 따르 면 그것이 인욕이라고 하였다.12) 마음이라는 것이 인심과 도심의 두 가지로 나뉘어 있는 것이 아니고 어떤 마음을 가지고 행동하는가에 따 라 도심도 되고 인심도 될 수 있는데, 인심은 인욕, 즉 육체의 욕구에 따라 행할 때 나타나며 도심은 보다 상세히 살펴서 하늘의 이치에 맞 게 따라 할 때 나타나는 것이다. 성인(聖人)에게도 인심이 있으나 성인 은 완전히 도심이 주관하므로 위태롭지 않다. 다만 성인도 인심뿐이라 면 위태롭기 때문에 생각하지 않으면 광인(狂人)이 된다.13) 주자에게 있어 맹자의 성선, 심선의 근원은 인심이 아니라 도심인 것이다.

한편 맹자가 심성을 분리하지 않고 같은 것으로 보는 것과 달리 주 자는 심에 대해 매우 분석적인 태도를 취하며 심(心)·성(性) · 정(情) 을 각기 다른 것으로 보고 있다. 주자에 의하면 성은 곧 이(理)이 다.14) 또한 주자는 심을 기(氣)의 정상(精爽), 그리고 앞에 인용된 것

11）朱喜, 『中庸章句序』, “心之虛靈知覺 一而已矣 而以爲有人心道心之異者 則以其或生 於形氣之私 或原於性命之正 而所以爲知覺者 不同 是以 或危殆而不安 或微妙而難見 耳. 然人莫不有是形 故雖上智 不能無人心 亦莫不有是性 故雖下愚 不能無道心 二者 雜於方寸之間 而不知所以治之 則危者愈危 微者愈微 而天理之公 卒無以勝夫人欲之私 矣…必使道心 常爲一身之主 而人心 每㯖命焉 則危者安 微者著 而動靜云爲 自無過 不及之差矣."

12) 성백효 역주, 『역주 심경부주』(서울: 전통문화연구회, 2018), p.40.

13) 같은 책, p.43. 
에서 알 수 있듯이 허령지각 등으로 묘사한다. 육체의 주체인 심에는 천리가 가장 온전하게 갖추어져 있는데, 그 심의 본체가 성이다. 즉 마음은 모두 이(理)를 갖추고 있는데 마음이 갖춘 이가 바로 성이며 그 이의 원천이 하늘인 것이다.15) 정에 대해서는 “성이란 심의 이요, 정이란 성의 동이요, 심이란 성과 정의 주(主)다”16)라고 구분하고 있 다. 즉 심이 주가 되어 그 이치를 말할 때 성이고, 움직임으로 나타날 때 정이라는 의미이다. 결국 인심도심에서의 도심은 성(이)를 일컫는 것이고 그것이 밖으로 드러날 때 정이 되는 것이다.

인격적 완성을 추구하는 수양론에 초점이 맞춰져 있는 퇴계에 있어 서도 심 - 성의 문제는 중요한 학문적 관심사였다. 퇴계는 이기론에 입 각해서 마음이 이와 기가 합쳐진 것으로 보았다. 개체의 마음에서 이 는 성(본성)이 되고 기는 이(성)를 싣는 그릇이다. 이기가 합해짐으로 써 허령지각이라는 마음의 기능이 있게 된다고 보고 있다.17) 또한 퇴 계는 인간의 인심과 도심을 기와 이로 나누고 다시 정(情)을 사단과 칠정으로 구분하여 사단을 이, 칠정을 기로 나누고 있다. 그리고 사단 은 순수하게 선이지만, 칠정은 선악이 혼재하고 있다고 한다. ${ }^{18)}$

인간의 선악이 왜 존재하는가에 대한 문제에 있어 퇴계는 이기호발 설(理氣互發說)을 근거로 해명한다. 사단과 칠정에 모두 이와 기가 있 지만 어느 것이 주가 되는가에 따라 이와 기가 되고 그것이 선과 악 을 판별하는 기준이 된다. 이렇게 본다면 앞에서 말한 사단이 순수하 게 선하다는 것과 모순이 된다. 그러나 이것은 주가 이와 기 가운데 어디에 있느냐에 따라 달라진다는 것이다. 즉, 이의 주재(主宰)가 강하 면 기는 약하여 이가 나타나고 이것이 주리(主理)이며 선이 나타나게 되고, 반대로 이의 주재가 약하면 기가 강해져서 기가 나타나고 이가

14）朱喜, 『中庸章句一』, “性師理也.”

15) 임헌규, 「유가의 인성론과 심성론」, 『동방학』 5 (1999), p.436.

16 ) 이동희, 「주자 심성론의 특징과 그 계승성」, 『공자학』1 (1995), p.208.

17 ) 김낙진, 「퇴계 이황과 율곡 이이의 심성론 비교」, 『율곡학연구』 12 (2006), p.57.

18) 서용화, 「퇴계의 인간관 연구」, 『퇴계학보』 70 (1991), pp.37-38. 
감추어지므로 선이 감추어지게 된다는 것이다.19) 따라서 사단은 이가 주재하므로 기가 약한 주리의 현상이며, 칠정은 기가 주재하므로 이가 약한 주기의 현상이라고 할 수 있다. 또한 기 자체가 악이 아니라 기 가 어떻게 작용하는가에 따라 악이 발생한다고 보고 있다.

이기 관계로 볼 때 퇴계가 마음은 구조적으로 이와 기가 합해진 것 이라고 본다면 율곡은 마음이 기라고 보고 있다. 율곡에게 성은 천리 가 사람에게 부여된 것이며, 성이 기와 결합하여 일신을 주재하는 마 음이 되고 마음이 사물에 응대하여 외부로 드러나는 것이 정이다.20) 퇴계와 다르게 율곡에게 마음이란 성과 기가 결합한 것이다. 천리가 부여된 성은 그 자체로 어떤 활동성이나 물질적 특성을 지닌 것이 아 니다. 인간의 본질을 이루고 있는 성은 곧 천리가 물리적 육체적 한계 를 지니면서도 성명(性命)이라는 비물리적인 특성이 결합된 인간을 구 성하는 원리이다. 인간의 본질적 특성을 이루는 성은 그 자체로 운동 의 특성을 갖는 것이 아니기 때문에 기의 조력을 필요로 하는 것이 다.21) 즉 움직여서 성을 외부로 드러내는 동력을 담당하는 것은 기이 기 때문에 이이는 마음의 움직임을 기라고 한 것이다.

율곡은 인심과 도심, 그리고 사단과 칠정에서도 퇴계와 다른 입장을 나타낸다. 퇴계는 인심과 도심, 그리고 사단과 칠정을 이와 기로 나누어 두 가지로 보고 있다. 그러나 율곡은 사단과 칠정을 서로 분리되지 않은 것으로 보고 있다. 즉 칠정 안에 사단이 포함되어 있다는 것이다. 인심 과 도심도 개념상 상대적으로 독립적인 것일 뿐 드러나는 서로 다른 성 격의 마음을 규정한 것이다. 모두 한 마음에서 유래하는 것은 마찬가지 이다. 선악의 문제에 있어서도 율곡에게 도심과 사단은 지선(至善)에 해 당하고 칠정과 인심을 선이나 불선(不善)으로 나누지 않고 있다.22)

19) 같은 글, p.39.

20）李珥，「人心道心圖說，『栗谷全書』卷 14 , “天理之賦於人者謂之性 合性與氣而爲主 宰於一身者謂之心 心應事物而發於外者謂之情.”

21) 김경호, 「율곡학파의 심학과 실학」, 『한국실학연구』 28 (2014), pp.56-57.

22) 조장연, 「율곡의 인성론 연구-사단칠정과 인심도심의 관계를 중심으로, 『한문고 전연구』12 (2006), pp.286-290. 
이처럼 유교에서는 맹자에서 마음의 문제를 거론한 이후 송대 성리 학을 거치며 마음에 대해 매우 분석적인 태도를 취하며, 마음의 선한 근거를 찾기 위해 노력하였다. 그것은 곧 인간이 왜 도덕적이어야 하 는가, 어떻게 성인에 이를 수 있는가를 찾는 노력이며 퇴계나 율곡의 수양론은 그 결과에 해당된다고 할 수 있다.

\section{III. 대순진리회에서의 마음}

증산이 마음(또는 心이나 一心)을 언급하는 내용은 『전경』에 백여 차례 이상 등장한다. 그것을 모두 언급하기에는 중복되는 것도 있고, 다른 목적에서 사용한 것도 있기에 부분적으로 중요하다고 생각되는 몇 가지를 중심으로 살펴볼 것이다. 증산이 마음에 대해 어떻게 생각 하는가를 파악해 볼 수 있는 가장 기본적인 가르침은 다음과 같다.

하늘이 비와 이슬을 박하게 베풀면 반드시 만방의 원이 생길 것이며, 땅이 물과 흙을 박하게 베풀면 반드시 만물의 원이 생 길 것이고, 사람이 덕화를 박하게 베풀면 반드시 만사의 원한이 생겨나게 된다. 하늘이 베풀고, 땅이 베풀고, 사람이 베푸는 것 은 모두 마음에 달려있는 것이다. 마음이란 귀신의 추기(樞機) 이며 드나드는 문이며 다니는 도로이다. 추기를 열고 닫으며 문 으로 드나들며 도로를 왕래하는 신은 혹은 선하기도 하고 혹은 악하기도 하니, 선한 것은 그대로 따르고 악한 것은 고쳐야 한 다. 내 마음의 추기와 문과 도로는 천지보다도 더 크다.23)

이 설명에 따른다면 세상의 모든 원한은 마음에 달려있다. 마음을

23)『전경』, 행록 3장 44절, “天用雨露之薄則必有萬方之怨 地用水土之薄則必有萬物之怨 人 用德化之薄則必有萬事之怨 天用地用人用統在於心 心也者鬼神之樞機也門戶也道路也 開閉 樞機出入門戶往來道路神 或有善或有惡 善者師之惡者改之 吾心之樞機門戶道路大於天地” 
어떻게 사용하는가에 따라 그것이 행동으로 옮겨지게 되고 그 결과 원이 생기기도 하고 그렇지 않기도 하는 것이다. 또한 마음은 신이 드 나드는 문이며 도로인데, 그곳에는 다양한 신들이 왕래한다. 그 신들 가운데는 선한 신도 있고 악한 신도 있다. 신의 의지에 따라 그대로 행동하게 되면 선한 신이 들어올 때는 선한 행동을 하게 되고 악한 신이 들어오면 악한 행동을 하게 된다. 따라서 사람들은 그것을 잘 알 아서 선한 것은 그대로 따르되 악한 신의 작용이 생기면 잘 고쳐서 선하게 되도록 이끌어야 하는 것이다. 즉, 마음의 작용에 따라 악이 될 수도 있고 선이 될 수도 있는 것이다. 이러한 모든 것은 바로 마음 에 좌우되는 것으로 그 영향은 사람에게만 해당되는 것은 아니다. 내 마음의 추기와 문과 도로는 천지보다도 더 큰, 즉 천지를 능가하는 것 이기 때문이다. 따라서 내가 어떤 마음을 갖느냐에 따라 온 천하에 영 향을 끼치는 것으로 이해할 수 있다.

장병길은 『전경』에 나와 있는 현무경의 도면24)과 위의 설명을 연 결시켜서 마음이 영(靈)이나 신을 감응할 수 있는 자리이기 때문에 심 령신대(心靈神臺)라고 하였다.25) 심령은 지극한 보배로 그것을 통하 면 귀신과도 서로 통하고 만물과도 함께 질서를 구할 수 있는 것이 다.26) 장병길에 의하면 상제로부터 심령신대를 갖추어서 태어난 인간 이 선천에서는 도수가 그릇되고 신명계에서 상극지리에 지배되었기 때문에 허물을 저지르게 되었다. 특히 그런 중에서도 인간들은 스스로 의 삶의 자리를 깨닫지 못하는 무지에 빠져서 탐욕 속에서 헤매고 있 었다.27) 상제로부터 심령신대를 갖춘 인간들이라면 도덕적으로 선하 거나 지극히 공평한 존재가 되어야 한다. 그러나 선천에서는 도수가 그릇되었기 때문에, 그리고 신명계의 상극하는 이치에 지배되었기 때

24) 같은 책, 교운 1장 66절, p.187.

25) 장병길, 『증산종교사상』(서울: 한국종교문화연구소, 1976), p.93.

26)『전경』, 교운 2장 41절, “心靈通則鬼神可與酬酢萬物可與俱序...”

27) 장병길, 앞의 책, p.94. 
문에 그럴 수 없었다고 이해할 수 있다.

한편 장병길은 다른 곳에서는 '심령을 신대로 삼고 $\cdots$ '라고 하여 심 령과 심대를 나누어서 보고 있다.28) 이것은 마음을 심령이라고 하고 그 심령은 신들이 거하는 곳, 앞의 인용문에서 보듯이 '귀신들의 추기 이며 신들이 드나드는 문'으로 이해할 수 있다. 다시 말해서 심령신대 란 마음을 심령으로, 그리고 그 심령은 신들과의 관계에서 신대로 이 해하는 것이다.

세상의 모든 원한이 마음에 달려있다는 것은 마음이 세상에서 차지 하는 위치를 말하기도 한다.

천지의 중심은 마음이다. 고로 동서남북과 몸이 마음에 의존 한다.29)

마음이 온 우주전체의 중심이며 그 안에 있는 모든 것이 마음에 의 존하는 것이다. 여기에서 천지란 단순히 물리적 공간만을 의미하기보 다는 그 안에 있는 모든 것을 일컫는 것으로 보아야한다. 일체의 모든 사물도 다 마음에 의존하며, 신들도 결국 마음에 의존하게 되는 것이 다. 따라서 선한 신이 들어오는 것은 그냥 우연히 들어오는 것이 아니 라 내 마음의 작용 때문이요, 악한 신이 들어오는 것도 내 마음이 작 용하기 때문이다. 우주 전체뿐만 아니라 몸도 마음에 의존한다고 하고 있으며 이는 인간의 신체가 마음에 따라 좌우됨을 말한다. 이렇게 본 다면 마음을 움직이는 주체는 바로 마음 자신이며 스스로 하는 행동 에 따라 그 결과가 나타나는 것이다. 조금 더 적극적으로 해석하면 내 가 마음을 먹는 기준에 따라 어떤 신이 들어오고 나가는지 결정된다. 내가 악한 마음을 먹으면 악신이, 선한 마음을 먹으면 선한 신이 내 마음에 들어오게 된다. 그 결과로 나의 행동이 선하게 나타나거나 악

28 ) 장병길, 『대순종교사상』(서울: 대순종교문화연구소, 1989), p.84.

29)『전경』, 교운 1장 66절, “天地之中央心也 故東西南北身依於心.” 
하게 나타나는 것이다. 즉 좋은 마음을 먹으면 좋은 신이 들어와 그 사람을 지배하게 될 것이며 나쁜 마음을 먹으면 나쁜 신이 들어와 그 사람을 지배하게 된다. 사람이 생각하고 마음먹음에 따라 신이 그 사 람에게 응하게 되는 것이다.30)

신인조화(神人調化)의 세계에서도 이것은 같은 의미로 연결된다. 대 순진리회에 의하면 다가올 후천세계는 인존시대(人䙷時代)이다. 따라 서 신인의 조화는 인간이 신에게 가는 것이 아니라 신이 인간에게 오 는 것이다. 그리고 그 신이 인간과 만나는 접점이 바로 마음이 된다. 마음은 우주전체의 중심이므로 모두가 마음에 의존한다. 따라서 마음 의 모습에 따라, 조금 다른 말로 하면 마음을 어떻게 먹느냐에 따라 다가올 신의 모습이 결정된다. 작은 마음을 가지면 좁은 신이, 큰마음 을 가지면 큰 신이, 네모의 마음이면 네모의 신이 응하는 것이다.31) 따라서 선과 악도 결국 마음의 작용에 따라 결정되는 것이다. 그것을 해결하고 선한 마음을 먹기 위해 끓임없이 노력해야 하며 부지런히 마음을 닦는 수밖에 없는 것이다.

악장제거 무비초 호취간래 총시화(惡將除去無非草 好取看來 總是花)라 말은 마음의 외침이고 행실은 마음의 자취로다. ${ }^{32)}$

외부의 상태가 어떠하던 간에 자신이 마음을 먹는 바에 따라 결과 는 달라질 수 있다는 것이다. 다시 말해서 억울한 일이나 악독한 일을 당하더라도 마음을 좋게 먹는다면 선한 결과를 얻게 되는 것이다. 이 러한 과정을 끊임없이 해 나가게 되면 누구를 대하더라도 어여삐 여 기고 사랑하게 된다. 대순진리회에서 제시하는 사강령 가운데 하나인 안심(安心)은 이렇게 자신의 마음속으로 들어오는 나쁜 신을 차단하고 이를 고쳐 써서 어떠한 경우에도 악한 쪽으로 마음이 기울지 않는 것

30) 정대진, 「안심 안신의 이해」, 『대순사상논총』 7 (1999), p.7.

31) 차선근, 「근대 한국의 신선 관념 변용」, p.158.

32)『전경』, 교법 1장 11절. 
을 말한다. 어떤 사람이 유혹을 하고 위협을 가해도 굴하지 않고 끝까 지 자신의 바른 도를 지켜나가는 것이 곧 안심인 것이다. 이처럼 마음 이 안정되었을 때 마음을 감싸고 있는 몸도 안정되는 안신(安身)로 이 루게 된다.33)

마음을 어떻게 먹느냐하는 것은 결국 한 순간에 되는 것은 아니고 지속적인 노력을 기울여야 한다. 그래서 증산은 마음을 어떻게 닦는 가에 따라 결과가 달라질 수 있음도 강조하고 있다.

공자(孔子)는 七十二명만 통예시켰고 석가는 픔명을 통케 하였으나 도통을 얻지 못한 자는 다 원을 품었도다. 나는 마음 을 닦은 바에 따라 누구에게나 마음을 밝혀 주리니 상재는 七 일이요, 중재는 十四일이요, 하재는 二十一일이면 각기 성도하 리니 상등은 만사를 임의로 행하게 되고 중등은 용사에 제한이 있고 하등은 알기만 하고 용사를 뜻대로 못하므로 모든 일을 행하지 못하느니라. ${ }^{34)}$

마음은 성인의 바탕으로 닦고 일은 영웅의 도략을 취하여야 되느니라. ${ }^{35)}$

사람마다 그 닦은 바와 기국에 따라 그 사람의 임무를 감당 할 신명의 호위를 받느니라. 남의 자격과 공부만 추앙하고 부러 워하고 자기 일에 해태한 마음을 품으면 나의 신명이 그에게 옮겨가느니라.36)

마음은 그것을 닦은 바에 따라 도통을 이룰 수 있고, 신명의 호위 도 받을 수 있는 것이다. 그러나 마음이 게을러 제대로 닦지 못한다면 나를 호위하는 신명조차도 다른 사람에게 옮겨갈 수 있다고 하여 마 음의 주재성을 강조함으로써 수양, 또는 수도를 통해 마음을 닦아야

33) 정대진, 앞의 글, p.11.

34)『전경』, 교운 1장 34절.

35) 같은 책, 교법 1장 23절.

36) 같은 책, 교법 2장 17절. 
함을 나타내고 있다고 볼 수 있다. 이것을 마음의 본성적 측면에서 생 각해 본다면 마음을 닦은 바에 따라 도통의 상중하가 결정될 것이지 만, 다른 식으로 이해하자면 본성을 얼마나 회복시켰는가에 따라 결정 되는 것으로 비유해볼 수 있다.

이와 같이 『전경』에서는 마음이 중요하며, 그러므로 마음을 잘 닦 아야 함을 강조하고, 또한 마음의 기능이나 개념37) 등을 언급하고 있 기는 하지만 마음의 본성이나 구조에 대해서 구체적으로 언급하지는 않았다. 『전경』뿐만 아니라 대순진리회에서는 마음을 잘 닦아야 한다 는 수도의 중요성은 이후에도 지속적으로 강조되고 있다. 우당은 "주 문만 읽는다고 되는 것이 아니며 마음을 고치고 수도해 나가는 것이 제일 중요한 일이다”라고 하여 주문 수련에 앞서 마음을 먼저 닦을 것을 강조하고 있다. 또한 “자고로 '마음이 참되지 못하면 뜻이 참답 지 못하고, 뜻이 참되지 못하면 행동이 참답지 못하고, 행동이 참되지 못하면 도통진경에 이르지 못할 것이라(心不誠 意不誠 意不誠 身不誠 身不誠 道不誠'하심을 깊이 깨달으라”고 하여 수도의 목적이 마음을 참답게 만드는데 있음을 분명히 했다.38)

그러나 이런 논의는 결국 마음의 여하에 따라 선도 되고 악도 가능 하다는 논리가 된다. 마음은 본성이 어떠하기에 선과 악이 모두 가능 할까, 또는 왜 마음은 선도 되고 악도 가능한 걸까에 대해 보다 구체 적인 근거가 필요하다. 그 근거는 『대순진리회요람』의 열 번째 항목인 훈회에 나타나 있다.

마음은 일신(一身)의 주(主)이니 사람의 모든 언어 행동은 마 음의 표현이다. 그 마음에는 양심(良心) 사심(私心)의 두 가지가 있다. 양심은 천성 그대로의 본심이요, 사심은 물욕에 의하여

37) 이경원은 『전경』에 근거를 두고 마음의 개념을 네 가지로 정리하였는데, 1) 천·지

- 인을 통제 제어하는 중추기구, 2) 신과의 교섭 장소, 3) 심령(心靈)으로서의 마음, 4) 몸의 주인으로서의 마음이 그것이다. 이경원, 「안심 안신에 관한 심성론적 해석」,

『대순사상논총』7 (1999), pp.531-535.

38) 차선근, 앞의 글, p.160. 
발동하는 옥심이다. 원래 인성의 본질은 양심인데, 사심에 사로 잡혀 도리에 어긋나는 언동을 감행하게 됨이니 사심을 버리고 양심인 천성을 되찾기에 전념하라. 인간의 모든 죄악의 근원은 마음을 속이는 데서 비롯하여 일어나는 것인즉 인성의 본질인 정직과 진실로써 일체의 죄악을 근절하라.39)

마음에는 양심과 사심의 두 가지가 있는데, 마음의 본바탕은 양심 이고 사심은 물욕, 즉 우리가 감각기관을 통해 사물이나 주변의 환경 을 받아들여서 생겨난 욕심을 말한 것으로 보인다. 그렇게 본다면 본 래 마음은 육체를 지배하고 육체는 마음에 종속되어야 하지만, 감각기 관인 육체에 의해 전송된 정보를 바탕으로 그 영향을 받아서 도리어 육체인 감각기관에 좌우되는 것이라고 볼 수 있다. 그런데 육체는 마 음의 지배를 받기 때문에 감각기관에 좌우된 마음에 따라 육체의 말 과 행동이 밖으로 드러나게 된다. 즉 감각기관에 의해 들어온 정보에 지배를 받는 사심이 작동하는가, 아니면 천성 그대로의 양심이 작동하 는가에 따라 육체의 행동이 나타난다. 사심을 이기고 양심에 따른 행 동을 한다면 선한 행동이, 반대로 사심이 양심에 앞장선다면 도리에 어긋나는 악한 행동이 나타나는 것이다.40) 사심은 인욕의 사사로움에 이끌려 생기는 것으로 천성에 반하는 마음의 작용이다.

마음에 대한 또 하나의 근거가 『대순지침』에 나타난다.

사(私)는 인심이요 공(公)은 도심(道心)이니, 도심이 지극하면 사심(私心)은 일어나지 못하느니라.41)

양심과 사심이라는 주제는 여기에서 도심과 인심으로 언급되고 있 다. 최치봉은 이를 지각의 기능으로 보고 주자의 주장을 근거로 하여

39)『대순진리회요람』(여주: 대순진리회 교무부, 2003), pp.18-19.

40) 이경원은 일심(一心)을 논하면서 양심과 사심이 양립하여 가치의 혼돈이 생긴 것 을 두마음으로 설명하면서 양심과 사심을 설명하고 있다. 이경원, 「대순사상의 심체 론 연구」, 『신종교연구』6 (2002), p.214.

41)『대순지침』(서울: 대순진리회 출판부, 1984), p.93. 
마음의 온전한 본체는 텅 비어 있고 밝아서 온갖 이치가 모두 갖추어 져 있으며 조금의 사사로운 욕망도 끼어들지 않기 때문이라고 하였 다.42) 사는 사사로운 욕망, 그리고 공은 공공의 도덕성으로 이해되는 데, 그런 점에서 차선근의 연구는 논의를 조금 더 복잡하게 전개할 수 있다. 차선근은 욕망에 긍정적인 욕망과 부정적인 욕망이 있음을 설명 하면서 욕망은 무조건 충족되어야 함을 주장한다. 다만 부정적인 욕망 을 충족시킬 경우 불행한 미래가 기다리고 있을 뿐이다.43) 부정적인 욕망은 사사로운 욕망인가, 그렇다면 긍정적인 욕망은 무엇인가라는 의문이 생긴다.

대순진리회의 입장에서 보자면 사심은 무조건 멀리하거나 일어나지 못하도록 해야 한다. 그런데 그것은 사심이 물질과 연결되어 있을 경 우이다. 물질과 연결되지 않은 사심도 있을까하는 의문이 든다. 만약 그렇다면 사심은 무조건 일어나지 못하게 하거나 피해야 하는 것은 아니기 때문이다. 물질과 연결되지 않은 사심을 긍정적 욕망으로 볼 수 있을지도 모르겠다. 아마도 이 부분은 단순하게 인심도심론과 사심 양심론으로 설명할 수 없는 부분이 될 것이다. 그것은 또 다른 문제인 인심이나 사심을 바로 인욕, 즉 인간의 욕망으로 귀결시킬 수 있는가 의 문제와 관련된다. 마음 자체와 그 마음에서 생성되는 욕망은 또 다 른 문제이기 때문이다. 그렇다고 하더라도 위의 인용문에서 도심이 지 극하면 사심이 일어나지 못한다는 것으로 보아 도심의 지극함을 양심 의 발현으로 이해할 수도 있지 않을까한다.

그런 면을 고려하더라도 양심이나 도심의 문제에 있어서는 분명한 것으로 보인다. 모든 죄악의 근원이 마음을 속이는 것에서 비롯된다는 것도 천성 그대로의 본심인 양심이나 도심을 속이는 것으로 설명되기 때문이다. 그러하기에 양심을 회복시키기 위해 노력해야 하며 사심에

42) 최치봉, 「주자학으로 본 대순사상의 마음에 관한 연구-허령, 지각, 신명을 중심으 로」, 대순사상논총』 31 (2018), p.251.

43 ) 차선근, 「대순진리회 마음관 연구 서설-해원과 감응을 중심으로, 『신종교연구』 36 (2017), p.121. 
얽매이지 않아야 하는 것이다. 그렇게 하기 위해 수도의 중요성이 강 조되고 있는 것이다. 수도를 통해 마음을 드러내야 하며 그것이 완전 히 발현되었을 때 대순진리회의 최종 목적인 지상신선, 지상천국이 가 능한 것이다. 다시 말해서 수도의 목적이 지상신선이지만 보다 구체적 으로 들어가면 마음의 선한 본성, 즉 천성인 양심을 일깨워서 그것을 온전히 드러내서 도덕성을 회복하는 것이 바로 목적이라고 할 수 있 다. 대순진리회의 목적이 지상천국이지만 그것은 결국 이러한 작용의 결과물이라고 생각할 수 있다.

\section{IV. 대순진리회의 심성론}

유교와 마찬가지로 대순진리회에서도 마음에 관한 문제는 중요한 주제이다. 『전경』에서 제시한 마음에 대한 개념은 신과 연결되어 있 다. 마음은 신을 맞이하며 신들이 드나드는 통로인데 어떤 신을 맞이 하는가에 따라서 마음이 그에 따르게 되며 그것이 행동으로 나타나게 된다. 따라서 여기에서는 마음이 선하거나 악하다는 전제가 마련되어 있지 않다. 마음 자체의 본성이 어떠한가에 대해 구체적으로 드러난 것은 아니다. 다만 마음은 인간과 우주의 중심이며 모든 사물이 마음 에 의존하고 있다는 의미를 제시하고 있다. 마음은 육체와 온 우주의 주재자로서의 위치에 있다. 따라서 마음의 작용에 따라 선과 악이 드 러나는 구조라고 이해된다.

맹자는 마음의 본성이 선하다고 보았는데, 그 근거로 사단을 제시 하고 있다. 선한 본성을 지닌 인간이 악을 저지르는 이유는 마음에 내 재된 본성에 따라 생각하지 않고 육체가 주는 정보에만 의존하여 그 에 맞게 행동하기에 악을 저지를 수 있는 것이다. 주자는 맹자의 이런 
입장을 받아들이면서도 맹자가 심과 성을 구분하지 않고 같은 것으로 보는 것과 달리 마음을 심·성·정의 세 측면으로 분석하여 심에 내 재된 리(理, 또는 天理)로서의 성과 심이 행동으로 나타난 측면인 정, 그리고 성과 정을 주관하는 마음이란 측면으로 보았다. 인간이 선이나 악을 행할 수 있는 이유로 선진시대 인심도심론을 설명하면서 도심을 따르면 선, 인심을 따르면 악을 저지를 수 있다고 보았다. 또한 성을 천명지성(天命之性), 또는 본연지성(本然之性)과 기질지성(氣質之性)으 로 구분하고 있다. 그러나 대개 지선(至善)한 본연지성과 기질지성은 별개의 성이 아니라고 말하고 있다.44)

퇴계의 경우는 다소 달라서 도심과 인심, 그리고 사단과 칠정을 이 와 기로 나누고 이기론을 통해 마음을 설명하려 한다. 다만 그의 경우 사단은 선이고 칠정은 악이라는 전제가 다를 뿐이다. 물론 이는 선에 해당되지만 기는 선도 악도 아니다. 율곡의 경우에는 사단과 칠정에 있어 퇴계와 다른 입장에 선다. 칠정이 사단을 포함하는 입장이다. 유 교의 입장에서 설명되는 마음은 천리가 개입되어 있기는 하지만 구조 적 요소일 뿐 인격적이거나 신적인 속성이 제시된 것은 아니다.45) 하 늘을 언급하고 있지만 이때의 하늘은 신적인 존재라기보다는 우주적 규범, 내지 이치로서의 하늘이기 때문이다.

한편 정산이 무극도를 창도한 이후 종지와 신조를 발표하면서 사강 령으로서 안심, 안신, 경천, 수도, 그리고 목적에 무자기가 포함된 것 은 이전에 강조되었던 마음의 중요성을 계승한 것이다. 마음의 흔들림 없는 안정을 통해 몸도 안정된다는 의미로 마음의 주재성을 다시 한 번 강조한 것이다. 또한 경천과 수도의 의미도 마음을 다하여 하늘을

44) 이동희, 앞의 글, pp.210-212.

45) 물론 정약용의 경우에는 설명이 다소 다르다. 그에게 도심이란 형이상학적으로 정 초되는 도덕원리이거나 태생부터 지닌 천성이 아니라 상제인 하늘이 일상의 시시각 각 모든 순간에 자신의 명령을 지속적으로 전해주는 것으로 보았다. 임부연, 앞의 글, p.96 참조. 
숭배하고 마음을 수도(또는 수련)한다는 의미가 있다고 본다.

『대순진리회 요람』에 있는 마음에 대한 보다 분석적인 내용을 통해 마음의 본성적 측면, 즉 심성에 대한 보다 심화된 논의를 진행시킬 수 있다. 그것은 바로 양심과 사심에 대한 언급이다. 양심을 천성 그대로 의 본심이라고 하는 것은 하늘의 이치를 받은 것, 곧 유교의 천리라고 할 수 있다. 천리는 인간의 사사로운 욕심인 인욕에 의해 생겨나는 사 심과는 다른 의미로서 '극진함이 털끝만한 인욕의 사가 없는'46) 공정 한 것이다. 따라서 유교의 도심이나 사단, 주자의 '성즉리'와 본연지성 등은 대순진리회의 심성을 이해하는데 도움을 줄 수 있다. 양심을 공 자의 인(仁), 또는 맹자의 양지(良知)로 이해한다면 보다 발전된 논의 가 이루어질 수 있다고 본다. 그렇게 본다면 양심이 바로 마음의 본성 이 되며 또한 인간, 또는 마음의 본성은 선하다는 결론에 이를 수 있 다. 그러한 마음의 본성을 드러내서 선을 완성시키는 것, 그리고 공공 의 도덕을 확충하는 것이 바로 수도의 목적임도 명확히 할 수 있다.

최치봉은 주자가 설명하고 있는 도심, 인심을 양심, 사심과 관련시 키고 있다. 주자학에서의 도심은 양심을, 그리고 인심은 사심을 말한 다는 것이다.47) 대순지침』에 등장하는 인심도심의 구분은 바로 사심 과 양심의 논리와 다름이 없기 때문이다. 다만 그 해석에 있어서는 어 느 한 가지로 간명하게 규명될 수 있는 것은 아니라고 생각한다. 유교 에서도 시대에 따라 해석에 차이점을 보이고 있으므로 어떤 것이 대 순진리회의 교리에 부합하는가의 문제가 제기될 수 있기 때문이다.

대순진리회의 심성에 관한 논의는 증산이 지속적으로 강조하고 있 는 일심(一心)이라는 주제와 관련해서도 설명될 수 있다. 마음의 본성 은 천성으로 본래 하나의 마음이지만, 감각기관에 의해 들어온 외부의

46) 『전경』, 행록 2장 17절.

47 ) 최치봉, 앞의 글, pp.250-251. 여기에서 주자학에서의 도심과 인심을 대순진리회 의 양심과 사심으로 바로 연결시키고 있는데, 주자학이라기보다는 주자의 설명이라 고 하는 것이 더 적절할 것이다. 
자극에 의해 잠시 허상인 사심이 생겨나고 마음은 마치 그것이 본심 인양, 그에 순응하여 행동하게 된다는 논리이다. 즉 양심과 사심이라 는 두 가지 마음을 제시하지만 본래의 마음이란 천성으로서의 양심일 뿐 사심은 허상에 불과한 것으로 성인(聖人)도 생각하지 않으면 광인 이 된다는 주자의 설명처럼 자세히 살펴 그것이 허상에 불과함을 깨 달아야 하는 것이다. 그래서 본래의 일심인 양심으로 돌아올 때 증산 이 강조한 일심이 되며 "일심을 가진 자는 한 손가락을 튕겨도 능히 만 리 밖에 있는 군함을 물리칠" 48 ) 정도의 능력을 발휘하는 것이다. 만일 사심이 실제로 인간이 가진 두 가지 마음의 하나라면 인간의 마 음 안에는 선과 악이 공존할 것이기 때문에 훈회에서 설명하는 '양심 은 $\cdots$ 본심이요, 사심은 $\cdots$ 발동하는 욕심이다'라고 하는 전제에 부합하 지 않게 된다. 말하자면 사심이란 본래 없다가 물욕으로 인해 생겨나 는 욕심이기 때문이다.

앞에서 보았듯이 인심도심론은 선진시대로부터 이후의 성리학에 이 르기까지 마음을 이해하는 주요한 설명체계 가운데 하나였다. 도심은 선천적인 천성, 천리로부터 비롯된 것으로 순수하게 도덕적이고 선하 다는 것이 주자의 도심에 대한 이해이다. 이에 비해 인심은 그 자체가 불선은 아니지만 감각기관에 의해 나타나는 모습과 옥구에 따라 불선 으로 발현될 수도 있는 것이다. 그런 면에서 보자면 양심을 도심으로 바꾸어도 차이는 없겠으나 사심을 바로 인심으로 대치하는 것은 다소 무리가 있어 보인다. 다만 사심이 허상에 불과하다거나 아니면 마음이 정으로 드러날 때 사적인 옥심의 영향으로 드러나는가, 본래적 도심이 나 양심으로 드러나는가에 따라 달리 드러날 뿐 본래 마음은 하나라 고 이해한다면 가능하다.

48)『전경』, 교법 3장 20절. 


\section{V. 나가는 말}

유교는 인간이 왜 도덕적이어야 하고 성인이 될 수 있는 방법이 무 엇인가에 대한 문제가 주요 관심사였다. 인격적 자아의 완성, 군자, 성인에 이르기 위한 방법인 수양론을 위해 맹자, 주자, 퇴계, 율곡 등 에게 마음이나 본성의 문제는 중요한 주제였다. 그들의 목적은 그 자 체가 아니라 완성된 인격을 바탕으로 여러 가지 사회문제를 해결하고 도덕적 이상사회를 구축하려는 것이 목적이었다. 즉, 인간이 도덕적이 어야 하는 문제는 인간이 본성이 선하기 때문이라는 맹자의 성선설을 바탕으로 논의가 전개되지만 결국 인간과 사회 모두에게 그것이 이롭 기 때문인 것이다. 즉, 인간은 선한 존재이기 때문에 당연히 선할 수 밖에 없고 또 그래야 한다는 주장이 유교적 논리이지만 그 결과로 나 타나는 것은 인간사회의 복지인 것이다.

방법론의 차이는 있지만 대부분의 종교에서 목적으로 삼는 것도 결 국은 현세, 또는 내세에서의 인간의 복지이다. 다만 그 방법론이나 세 계나 인간을 바라보는 관점의 차이들이 존재할 뿐이다. 그런 면에서 대 순진리회가 목적으로 삼는 지상신선의 세계, 지상천국의 세계, 즉 후천 개벽의 세계는 이상향의 세계이면서 모든 사람들이 꼼꾸는 세계이다. 마음을 수도하고 선을 추구하는 것도 결국은 후천개벽의 세계를 만들기 위함이다. 온 우주의 중심이 마음이며 마음의 행동에 따라 세계의 변화 도 이루어질 수 있다는 점에서 대순진리회에서도 마음에 대한 관심은 중요한 문제가 아닐 수 없다. 그렇지만 대순진리회에서 아직 독립적으 로 심성에 대한 논의를 전개한 연구는 많지 않다. 앞에서 언급한 이경 원의 심체론 연구도 실제로는 심체 자체에 대한 논의보다는 심체의 기 능과 현현, 그리고 수행적인 측면에 초점이 맞추어져 있다.49)

49) 이외에 앞의 각주 43 에서 본 차선근의 연구도 있다. 그는 해원과 감응이라는 용어 를 사용하며 마음에 대한 논의를 전개한다. 차선근이 규정한 마음이란 1) 의지를 일 
심성론과 심체론은 마음의 구조와 작용 이외에 본성 등을 밝히는 문제로의 접근도 필요하다. 이것은 선과 악, 그리고 도덕의 문제로 연 결되며, 그것을 위한 수양의 문제, 즉 수도의 문제와 연결되기 때문이 다. 다시 말해서 대순진리회에서 가르치는 마음의 근원, 본성 등에 대 한 이해를 통해 수도의 중요성이 함께 이해될 수 있고 이는 결국 종 교적 신앙, 믿음에 대한 확실한 근거를 제시할 수 있다. 물론 그렇다 고 해서 마음의 구조와 작용이 중요하지 않다는 것은 아니다. 본성 못 지않게 그 부분도 중요하지만 본고에서는 마음의 구조와 작용 이외에 본성에 대해 조금 더 접근했을 뿐이다. 그래도 아직 확실하게 선과 악 의 근거, 도덕의 근거에 대한 제시에는 이르지 못했다고 생각한다.

이에 덧붙여 증산이 언급한 마음의 내용도 기초를 이루겠지만, 여기 에서 조금 더 나아가서 현재 대순진리회의 뼈대인 종지, 신조, 사강령, 삼요체, 목적 등이 모두 도주인 정산에 의해서 이루어졌기 때문에 그 것들과 관련된 심성 연구의 폭을 넓혀볼 필요가 있다. 『전경』에서 언 급된 마음을 중심으로 한 연구에서 대순진리회 이후의 내용을 중심으 로 우당의 훈시나 요람, 그리고『대순지침』등을 근거로 보다 발전된 연구가 있어야 하리라고 본다. 그럼으로써 마음에 대한 이해의 지평을 넓혀 나가면 그것 또한 수도의 중요성과 연결될 수 있다고 생각된다.

으키는 기관, 2) 욕망을 일으키는 기관, 3) 외재적 신명이 감응하는 기관이다. 이러한 마음관을 전개하면서 강조되는 것은 역시 마음수련, 또는 수행이다. 이 글에서 양심 사심론을 별도의 소제목으로 할애하고 있지만, 구체적인 분석보다는 기능이나 수행 의 문제로 접근하고 있다. 차선근, ‘대순진리회 마음관 서설-해원과 감응을 중심으 로」참조. 


\section{【참 고 문 헌 】}

『전경』, 여주: 대순진리회 출판부, 2010.

『대순지침』, 서울: 대순진리회 출판부, 1984.

『대순진리회요람』, 여주: 대순진리회 교무부, 2003.

『孟子』

『書經』

『栗谷全書』

『中庸章句』

김경호, 「율곡학파의 심학과 실학」, 『한국실학연구』 $28,2014$.

http://uci.or.kr/G704-001622.2014..28.003

김낙진,「퇴계 이황과 율곡 이이의 심성론 비교」, 『율곡학연구』 $12,2006$. 서용화, 「퇴계의 인간관 연구」, 『퇴계학보』, 70, 1991.

성백효 역주, 『역주 심경부주』, 서울: 전통문화연구회, 2018.

윤지원, 「선진유가인성론소고」, 『공사논문집』 65, 2014.

이경원, 「안심 안신에 관한 심성론적 해석」, 『대순사상논총』 $7,1999$.

「대순사상의 심체론 연구」, 『신종교연구』 6, 2002.

이동희, 「주자 심성론의 특징과 그 계승성」, 『공자학』 $1,1995$.

이상은, 「선진유학의 근본문제와 전승관계에 관한 고찰-공자- 맹자·순 자의 천인관, 심성론을 중심으로」, 『동양철학연구』17, 1997.

임부연, 「정약용 마음론의 구조와 쟁점-주희와의 비교를 중심으로」, 『종 교학연구』20, 2001.

임헌규, 「유가의 인성론과 심성론」, 『동방학』5, 1999.

장병길, 『증산종교사상』, 서울: 한국종교문화연구소, 1976.

"대순종교사상』, 서울: 대순종교문화연구소, 1989.

정대진, 「안심 안신의 이해」, 『대순사상논총』 $7,1999$.

조장연, 「율곡의 인성론 연구-사단칠정과 인심도심의 관계를 중심으로」, 『한문고전연구』12, 2006. 
최치봉, 「주자학으로 본 대순사상의 마음에 관한 연구-허령, 지각, 신명 을 중심으로」, "대순사상논총』 $31,2018$.

http://doi.org/10.25050/jdaos.2018.31.0.237

차선근, 「근대 한국의 신선 관념 변용」, 『종교연구』 62, 2011.

http://doi.org/10.21457/kars..62.201103.139

— 대순진리회 마음관 연구 서설-해원과 감응을 중심으로」, 『신종교 연구』36, 2017. http://doi.org/10.22245/jkanr.2017.36.36.111

馮友蘭, 『중국철학사』상권, 박성규 옮김, 서울: 까치글방, 2013. 


\section{유교와 대순진리회의 심성론 비교 연구}

국문요약

윤용복

심성론(心性論)이란 말 그대로 인간이 지닌 마음의 본성에 대한 것 을 설명하는 것이다. 다시 말해서 인간은 마음이란 것을 지니고 있는 데, 그것이 과연 무엇인가, 그리고 어떤 성품을 지녔는가를 알아보는 것이다. 여기에서는 유교의 심성론과 관련시켜서 대순진리회의 심성론 을 이해하려 하였다.

유교와 마찬가지로 대순진리회에서도 마음에 관한 문제는 중요한 주제이다. 『전경』에서 제시한 마음에 대한 개념은 신과 연결되어 있 다. 그런데 여기에서는 마음이 선하거나 악하다는 전제가 마련되어 있 지 않다. 다만 마음은 인간과 우주의 중심이며 모든 사물이 마음에 의 존하고 있다는 의미를 제시하고 있다. 마음의 작용에 따라 선과 악이 드러나는 구조라고 이해된다. 『대순진리회 요람』에는 양심과 사심에 대해 언급하고 있다. 양심을 공자의 인(仁), 또는 맹자의 양지(良知)로 이해한다면 보다 발전된 논의가 이루어질 수 있다고 본다. 그렇게 본 다면 양심이 바로 마음의 본성이 되며 또한 인간, 또는 마음의 본성은 선하다는 결론에 이를 수 있다.

심성에 관한 논의는 증산이 지속적으로 강조하고 있는 일심(一心) 이라는 주제와 관련해서도 설명될 수 있다. 양심과 사심이라는 두 가 지 마음을 제시하지만 본래의 마음이란 천성으로서의 양심일 뿐 사심 은 허상에 불과한 것으로 성인(聖人)도 생각하지 않으면 광인이 된다 는 주자의 설명처럼 자세히 살펴 그것이 허상에 불과함을 깨달아야 하는 것이다. 그래서 본래의 일심인 양심으로 돌아올 때 증산이 강조 한 일심이 된다. 말하자면 사심이란 본래 없다가 물욕으로 인해 생겨 
나는 욕심이다.

인심도심론은 선진시대로부터 이후의 성리학에 이르기까지 마음을 이해하는 주요한 설명체계 가운데 하나였다. 도심은 선천적인 천성, 천리로부터 비롯된 것으로 순수하게 도덕적이고 선하다는 것이 주자 의 도심에 대한 이해이다. 이에 비해 인심은 그 자체가 불선은 아니지 만 감각기관에 의해 나타나는 모습과 욕구에 따라 불선으로 발현될 수도 있는 것이다. 그런 면에서 보자면 양심을 도심으로 바꾸어도 차 이는 없겠으나 사심을 바로 인심으로 대치하는 것은 다소 무리가 있 어 보인다. 다만 사심이 허상에 불과하다거나 아니면 마음이 정으로 드러날 때 사적인 욕심의 영향으로 드러나는가, 본래적 도심이나 양심 으로 드러나는가에 따라 달리 드러날 뿐 본래 마음은 하나라고 이해 한다면 가능하다.

주제어 : 대순진리회, 심성론, 일심, 양심사심론, 도심인심론, 수양론 